\title{
Overcoming telomeric silencing: a trans-activator competes to establish gene expression in a cell cycle-
dependent way
}

\author{
Oscar M. Aparicio and Daniel E. Gottschling \\ Department of Molecular Genetics \& Cell Biology, University of Chicago, Chicago, Illinois 60637 USA
}

\begin{abstract}
Genes located near telomeres in yeast are subject to position-effect variegation. To better understand the mechanism of this variegation, we investigated how a telomeric URA3 gene switches from a silent to an expressed state. We found that silencing of a telomeric URA3 gene was attributable to the elimination of its basal transcription. The reversal of that silencing was dependent on the presence of PPR1, the trans-activator protein of URA3. Maximum expression of URA3 required a higher concentration of PPR1 when URA3 was telomeric compared with when it was at a nontelomeric location. The ability of PPR1 to overcome silencing varied at different points in the cell cycle. In cells arrested in $G_{2}$ /metaphase, PPR1 was able to activate transcription of a telomeric URA3, but in cells arrested in $G_{0}, G_{1}$, or early $S$ phase it was not. In comparison, a nontelomeric URA3 could be activated by PPR1 at all times. We conclude that once established, telomeric silent chromatin is a relatively stable structure, making a gene recalcitrant to activation. Following the disassembly of silent chromatin during DNA replication, competition of assembly ensues between components of telomeric chromatin, to establish a silent state, and the trans-activator, to establish gene expression. These results help explain the stochastic nature of phenotypic switching in variegated gene expression.
\end{abstract}

[Key Words: Chromatin; position-effect variegation; Saccharomyces cerevisiae; telomeres; trans-activators; cell cycle]

Received February 22, 1994; revised version accepted April 12, 1994.

In multicellular eukaryotes, chromosomal position effects generally involve the repression of a euchromatic, wild-type gene when it has been placed in or near heterochromatin as the result of a chromosomal rearrangement (for review, see Lima-de-Faria 1983). In a population of cells with such a rearrangement, the gene may escape repression; consequently, the resulting phenotype is variegated, exhibiting patches of normal and mutant tissue. A classic example of this phenomenon is the mosaic red-and-white eye of Drosophila in which the white gene has been translocated within centromeric heterochromatin (for review, see Eissenberg 1989; Henikoff 1990; Spradling and Karpen 1990).

When a wild-type gene is located near a telomere in the budding yeast Saccharomyces cerevisiae, it too is subject to position-effect variegation (Gottschling et al. 1990). For instance, when yeast cells with the $A D E 2$ gene placed near a telomere form a colony on solid medium, the colony is composed of subpopulations in which the $A D E 2$ gene is either expressed (white sectors) or repressed (red sectors). The different phenotypes of the sectors in a colony reflect the ability of genetically identical cells to switch between phenotypic states. The fact that large sectors are phenotypically uniform reflects the ability of each state to be heritably propagated for multiple generations. Similarly, yeast cells with a telomeric $U R A 3$ gene can form colonies on medium containing 5-fluoro-orotic acid (5-FOA), a drug lethal to cells expressing URA3 (Boeke et al. 1987), indicating that the cells are phenotypically $\mathrm{ura}^{-}$. However, these 5-FOAresistant cells can form colonies when placed on medium lacking uracil; thus, the cells are able to switch their phenotypic status by activating expression of the telomeric URA3 gene (Gottschling et al. 1990).

Silencing of telomeric genes in S. cerevisiae is likely attributable to a structurally distinct chromatin domain that initiates at the telomere. Evidence for this specialized chromatin structure includes identification of mutations in the histone $\mathrm{H} 3$ and $\mathrm{H} 4$ genes that relieve telomeric silencing (Aparicio et al. 1991; M. Grunstein, pers. comm.), the finding that telomere-adjacent chromatin contains histone $\mathrm{H} 4$ in a hypoacetylated state compared with $\mathrm{H} 4$ in actively transcribed chromatin regions of the genome (Braunstein et al. 1993), and the relative inaccessibility of telomere-proximal DNA to in vivo modification by the Escherichia coli dam methyl- 
transferase protein (Gottschling 1992). In addition, the frequency with which a gene is silenced decreases with increasing distance from the telomere, suggesting that the structure nucleates at the telomere and the extent of its inward assembly along the chromosome varies between cells (Renauld et al. 1993). The extent of this assembly is proportional to the cellular concentration of SIR3, a gene product required for silencing at telomeres and the silent mating loci, $H M L$ and $H M R$ (Aparicio et al. 1991; Laurenson and Rine 1992; Renauld et al. 1993). These results suggest that SIR3 is rate-limiting for assembly of the silent chromatin structure and implicate SIR3 as a component of the silent structure.

Two intriguing questions that arise in the study of position-effect variegation are how does a gene switch between phenotypic states; and once a state is determined, how is it heritably propagated? Both questions have been considered in fundamental issues of developmental biology. In particular, a great deal of interest has been focused on the role of transcriptional regulation in addressing these questions (for review, see Brown 1984; Weintraub 1985). With respect to position-effect variegation and the first question, two models of regulation that involve a role for chromatin structure have evolved (for review, see Felsenfeld 1992). Both models propose that transcription of a gene is inhibited by assembly of its DNA into chromatin. Furthermore, one or more transcriptional activator proteins (trans-activators) bind in a sequence-specific manner to DNA located in proximity to the gene and facilitate transcription of that gene, thus overcoming the repressive nature of the chromatin. Where the models differ is that in one case chromatin prevents the trans-activator from gaining access to the DNA, in essence keeping the gene "irreversibly" repressed. However, during DNA replication the chromatin structure of the gene is perturbed and the trans-activator has the opportunity to gain access and establish transcription before reassembly of the chromatin is completed. In the second case, the trans-activator can induce gene transcription at anytime in a replication-independent manner, effectively disrupting the repressive nature of the chromatin.

At its normal locus, URA3, like many biosynthetic pathway genes, is constitutively expressed at a basal level but can be induced to higher levels of expression (Lacroute 1968). URA3 induction is contingent upon binding of an activated form of the trans-activator PPR 1 to the upstream activating sequence (UAS) of the gene (Losson and Lacroute 1981; Roy et al. 1990). Interestingly, when $U R A 3$ is located adjacent to a telomere, its basal level of expression may be repressed because the cells are phenotypically ura3- (Gottschling et al. 1990).

In our attempt to comprehend position-effect variegation, we have focused on how a gene switches between phenotypic states. We report on our efforts to understand how a gene located near a telomere overcomes silencing. Specifically, we examined the role of PPRl in the expression of a telomeric URA3 gene. Our results lead us to conclude that silent telomeric chromatin inhibits basal expression of $U R A 3$ and prevents the transcriptional ac- tivation of the telomeric $U R A 3$ gene by PPR 1 during the $\mathrm{G}_{1}$ and early $\mathrm{S}$ phases of the cell cycle, in addition to when cells are arrested in $G_{0}$. Furthermore, our results suggest that upon replication of the telomeric DNA, a competition takes place between assembly of a silent chromatin structure and assembly of a PPR1-mediated transcriptionally active gene. These findings provide a peek into the mechanism of transcriptional control by silent chromatin and the establishment and inheritance of transcriptional states.

\section{Results}

The URA3 trans-activator PPR1 is required for overcoming telomeric silencing of URA3

To test the idea that the trans-activator PPRl plays a role in overcoming silencing of a telomere-linked URA3 gene, the PPR 1 gene was deleted from a strain in which URA3 was located adjacent to telomere VII-L (UCC1001). To determine whether deletion of PPR1 had a specific effect on $U R A 3$ expression at a telomere, $P P R 1$ was also deleted in a strain with URA3 inserted at an internal chromosomal position, the $A D H 4$ locus, which is $\sim 20 \mathrm{~kb}$ from telomere VII-L (UCC1003). PPR1 was also deleted in a strain lacking URA3 (ura3-52; YPH250). URA3 expression was measured by two methods: plating viability assays on medium containing 5-FOA and on medium lacking uracil (-URA), and RNA blot hybridization analysis. 5-FOA is converted into a toxic metabolite by the $U R A 3$ gene product, such that cells expressing normal levels of the URA3 gene product are sensitive to 5-FOA, whereas cells that lack it are resistant to 5-FOA (Boeke et al. 1984). For the RNA analysis, transcript levels were analyzed from URA3, URA1, and ura3-52 [(Rose and Winston 1984) in this allele the URA3 transcript is truncated], each of which is regulated by the PPR1 protein (Losson and Lacroute 1981). Thus, URA1 and ura3-52 RNA levels reflect the in vivo level of PPR 1 activity as a transcriptional activator in each experimental sample.

Figure 1 shows that $P P R 1$ is required for overcoming silencing of the telomeric URA3 gene. Wild-type $\left(P P R 1^{+}\right)$cells with $U R A 3$ near a telomere formed colonies on 5-FOA medium and medium lacking uracil. This reflects the ability of the telomeric $U R A 3$ gene to switch between transcriptionally repressed and active states. Deletion of PPR 1 abolished the ability of cells with a telomeric URA3 gene to grow in the absence of uracil (Fig. 1A). Deletion of the PPR1-binding site within the URA3 gene promoter had the same effect as deletion of $P P R 1$, indicating that specific binding of PPR1 at the URA3 UAS was required for overcoming silencing (Fig. 3, below; UAS ${ }_{G A L}-U R A 3-T E L$, GAL4 plasmid " -", the strain is $P P R 1^{+} \mid$. Thus, in this telomeric context, PPR 1 is required for the transcriptional activation of the URA3 gene. The very small colonies that arose on - URA medium from the $p p r 1^{-}$strain with a telomeric URA3 gene had acquired trans-acting mutations or local chromosomal rearrangements that permitted expression of 


\section{A}

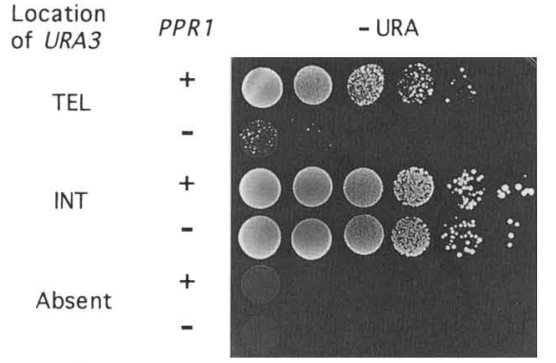

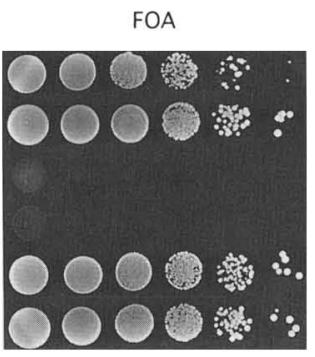
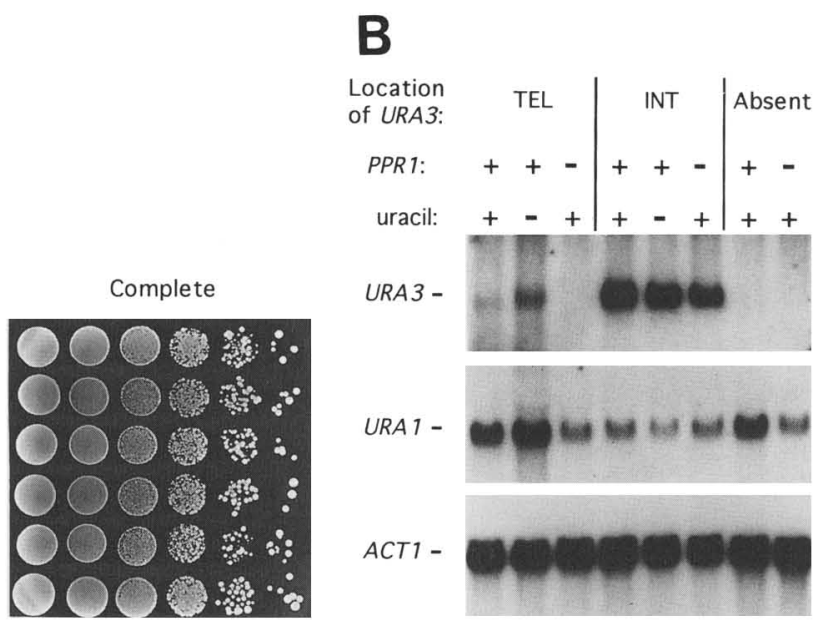

Figure 1. Expression of a telomere-linked URA3 gene requires PPR1. (A) Plating efficiency of strains with URA3 present at a telomeric (TEL) (UCC1001, UCC111) or internal (INT) (UCC1003, UCC113) chromosomal locus or absent (YPH250, UCC115), having PPR1 present $(+)$ or deleted $(-)$. Cells were grown for 3 days on nonselective medium, suspended in $\mathrm{H}_{2} \mathrm{O}$, and equivalent aliquots of tenfold serial dilutions were placed onto complete synthetic medium (Complete), medium lacking uracil (-URA), and medium containing 5-FOA (FOA). (B) RNA blot hybridization analysis of strains in $A$. Total RNA isolated from mid-log-phase cells grown in medium containing uracil $(+\mid$ or lacking uracil $|-|$, was electrophoretically separated and blotted to nylon. The blot was sequentially hybridized with ${ }^{32}$ P-labeled $U R A 3$ and $A C T 1$ antisense RNA probes, and a URA1 DNA probe.

URA3 (M.S. Singer and D.E. Gottschling, unpubl.). Therefore, essentially no URA3 gene product was produced from this telomeric site when PPR1 was absent from the cell. In contrast, deletion of $P P R 1$ had no effect on 5-FOA or - URA viability when URA3 was located at an internal chromosomal locus, (there is a slight decrease of colony size on -URA; Fig. 1A). This result suggests that at an internal location transcription of $U R A 3$ still occurs, independently of PPR 1 , and is consistent with $U R A 3$ regulation at its normal chromosomal locus (Losson et al. 1985). As expected, PPR1 deletion had no effect on the plating viability of cells lacking a functional URA3 gene (Fig. 1A).

Telomeric URA3 mRNA was undetectable when $P P R 1$ was deleted (Fig. 1B). However, PPR $1^{+}$cells with a telomeric URA3 maintained the ability to activate $U R A 3$ transcription. Deletion of PPR1 had little or no effect on expression of an internal copy of $U R A 3$, or on expression of URA1.

Both the plating viability on -URA medium and the RNA analysis indicate that the constitutive or basal (PPR1-independent) expression of URA3 at telomere VII-L is repressed by the telomeric silencing machinery. However, the trans-activator PPR 1 is able to circumvent the telomeric repression, thus facilitating URA3 expression.

\section{Increased PPR1 dosage prevents silencing} of a telomeric URA3

Because a telomeric $U R A 3$ could exist in either an active or repressed state, and because PPR1 was required for the active state, we postulated that PPR1 might compete against the assembly of a repressed state. If this hypoth- esis were true, then increasing the dosage of $P P R 1$ should increase the frequency with which an active state is established. To test this hypothesis, PPR1 was expressed from a multicopy plasmid (FAT-PPR1, FAT is the vector alone) in strains with URA3 absent, URA3 at a telomeric, or $U R A 3$ at an internal chromosomal locus. Cell viability of the resulting strains was quantified on 5-FOA medium and medium lacking uracil (Fig. 2). Increase of PPR1 protein concentration from FAT-PPR 1 [verified by ura3-52 and URA1 RNA levels and quantitative electrophoretic mobility shift analyses (EMSAs; data not shown)] resulted in complete 5-FOA sensitivity of cells with $U R A 3$ at the telomeric locus, along with improved growth on - URA. As expected, viability was not affected by overproduction of PPR 1 when URA3 was at the internal locus or absent. Thus, high levels of PPR 1 compete against telomeric silencing to perpetually re-establish the $U R A 3$ gene in an active state. These results also suggest that in a wild-type cell, the concentration of PPR1 is limiting for telomeric URA3 expression.

\section{GAL4 can overcome telomeric silencing}

To determine whether the ability of PPR1 to overcome telomeric silencing on $U R A 3$ transcription was a general characteristic of transcriptional activator proteins, the PPR1 binding-site upstream of the URA3 gene was replaced with a binding site for the GAL4 trans-activator protein (Verdier 1990). This modified URA3 gene (UAS$G A L^{-U R A 3)}$ was placed next to telomere VII-L (UCC420) or within the $A D H 4$ locus (UCC419) in strain YM725 ( $\mathrm{gal4}^{-}, \mathrm{gal}^{-} \mathrm{O}^{-}$, ura3 $\left.{ }^{-}\right)$. The gal80 mutation relieves negative regulation of the GAL4 protein so that activity of GAL4 is proportional to its concentration (Johnston 
Figure 2. Silencing of a telomere-linked $U R A 3$ gene can be reversed by overexpression of PPR1. Plating efficiency, as described in Fig. 1A, of strains with URA3 present at a telomeric (TEL) (UCC1001) or internal (INT) (UCC1003) chromosomal locus or absent (YPH250), which contained the PPR1-overproducing plasmid (FATPPR1) or the vector alone (FAT) on complete synthetic medium (Complete), medium lacking uracil (-URA), and medium containing 5-FOA (FOA). All media lacked tryptophan to maintain selection for the plasmids.
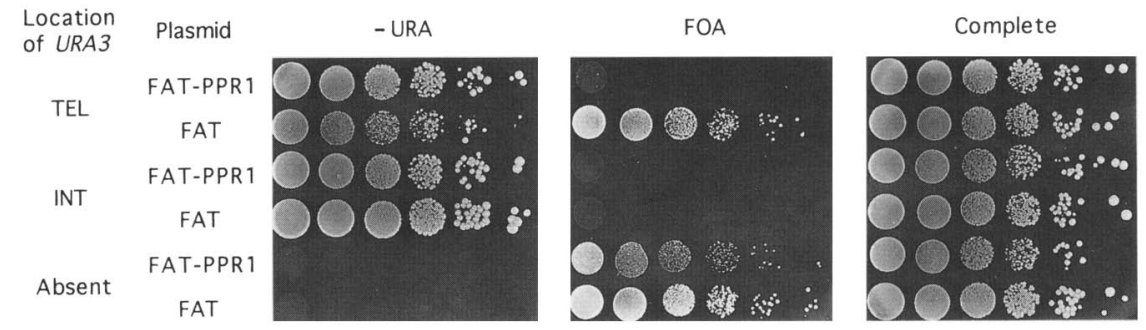

1987). $U A S_{G A L}-U R A 3$ was silenced when placed at telomere VII-L, as the cells were 5-FOA resistant and $\mathrm{Ura}^{-}$, but $U A S_{G A L}-U R A 3$ was not repressed when internally located on the chromosome as cells were 5-FOA-sensitive and URA ${ }^{+}$(Fig. 3, GAL4 plasmid - ).

The wild-type GAL4 protein or a series of carboxyterminal truncations of the GAL4 protein were expressed in the strains with $U A S_{G A L}-U R A 3$ located at the telomere or at the internal locus. The carboxy-terminal truncation derivatives of GAL4 maintain the amino-terminal DNA-binding domain and bind to UASGAL in vitro but are defective in transcriptional activation in vivo (Johnston and Dover 1988). Expression of wild-type GAL4, from a single copy centromeric plasmid, completely reversed silencing of the telomeric $U A S_{G A L^{-}} U R A 3$, as indicated by the sensitivity of this strain to 5-FOA and robust growth on - URA medium (Fig. 3). None of the truncated GAL4 derivatives were able to activate $U A S_{G A L}-U R A 3$ adjacent to the telomere. Expression of GAL4 or its derivatives had no effect on 5-FOA-sensitivity, or - URA viability, of strains with $U A S_{G A L}-U R A 3$ located internal on the chromosome. It appears that the activation domain of GAL4 is required to compete for telomeric gene expression. These results suggest that the ability to overcome telomeric silencing is a general function of trans-activators.

\section{Modulating the dosage of $P P R 1^{c}$ reveals that its accessibility to the telomeric URA3 gene is limited}

The finding that PPR 1 dosage has a demonstrable effect on telomeric URA3 expression, but not for internal URA3 expression (Figs. 1 and 2), suggested that the telomeric $U R A 3$ gene is relatively resistant to transcriptional activation by PPR 1 compared with when URA3 gene is nontelomeric. To investigate this, a chimeric gene, GALPPR1-1, was constructed with the coding sequence of the PPR1-1 allele under control of the GAL1,10 promoter (Johnston and Davis 1984). The PPR1-1 allele encodes a constitutively active protein, $P P R 1^{c}$; thus, the level of PPR $1^{c}$ activity as a trans-activator is directly proportional to its total cellular concentration (Losson and Lacroute 1983). The GAL1,10 promoter permitted precise regulation of PPR $1^{c}$ protein concentration within the cell (Durrin et al. 1991), because the intracellular level of $P P R 1^{\mathrm{c}}$ was proportional to the level
Figure 3. Expression of a telomere-linked $U A S_{G A L}-U R A 3$ gene requires the activation domain of the GAL4 trans-activator protein. Plating efficiency, as in Fig. 2, of gal4 gal80 strains that had UAS $S_{G A L}-U R A 3$ [URA3 gene with the PPR]-binding site $\left(U_{\text {UAS }}\right)$ replaced by the GAL4-binding site $\left[\mathrm{UAS}_{\mathrm{GAL}}\right.$ )] at a telomeric (TEL) (UCC420) or internal (INT) (UCC419) chromosomal locus, and contained a plasmid expressing the wild-type GAL4 protein (WT-881) or a plasmid expressing a carboxy-terminal truncation of GAL4 at amino acids $292,684,174$, or 383 the numbers also denote the respective plasmids), or no plasmid $(-)$. All media contained $3 \%$ raffinose as the sole carbon source and lacked tryptophan to maintain selection for the plasmids, except the media used for the strains harboring no plasmid that did contain tryptophan.

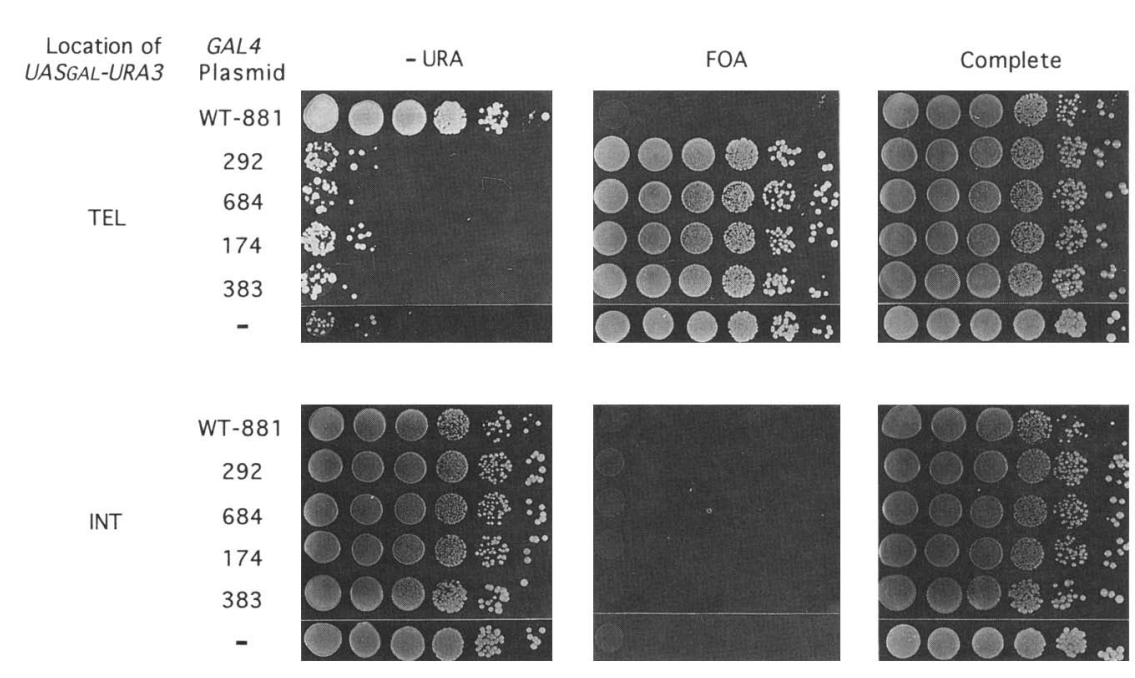


of galactose in the medium [based on ura3-52 RNA levels (Fig. 4) and quantitative EMSAs (data not shown)]. As a control, a nonfunctional version of the gene fusion (GALppr1-1), which contains an inversion within the PPR1-1-coding sequence, was also created. These gene fusions were inserted at the leu2 locus in isogenic ppr1strains containing URA3 at a telomeric (UCC2016) or internal chromosomal locus (UCC431) or in which URA3 was absent (UCC432).

The resulting strains were tested for viability on 5-FOA and - URA medium that also contain galactose. Expression of the GALPPR1-1 fusion, but not the mutated GALppr1-1 fusion, effectively overcame silencing of the telomeric URA3 in all cells of the population; the cells were URA ${ }^{+}$and 5 -FOA sensitive (data not shown). Expression of GALPPR1-1 or GALPpr1-1 had no effect on the 5-FOA sensitivity or the - URA viability of strains with URA3 either at the internal locus or absent (data not shown).

Levels of mRNA were analyzed from these strains grown in rich medium containing $3 \%$ raffinose and $0.25 \%$ galactose, which induced expression of GALPPR1-1 or GALppr1-1. Expression of GALPPR1-1 strongly activated transcription from $U R A 3, U R A 1$, and ura3-52, although compared with expression of the internal URA3 gene, expression of the telomeric URA3 was reduced (Fig. 4A). Equivalent levels of PPR $1^{\mathrm{c}}$ activity [based on URA1 and ura3-52 mRNA levels (Fig. 4A), and EMSAs (data not shown)] were present in the GALPPR1-1 strains. This result supports the idea that compared with the internal URA3, the telomeric URA3 gene is relatively resistant to transcriptional activation at this concentration of PPR $1^{\mathrm{c}}$.

We compared the relative expression levels of the telomeric URA3 gene and the internal URA3 gene when different concentrations of $P P R 1^{c}$ protein were expressed. The level of ura3-52 RNA was used as a standard for PPR $1^{c}$ concentration in vivo in comparing the two URA3 loci; ura3-52 has the same upstream sequences as $U R A 3$ and is responsive over a wide range of $P P R 1^{c}$ concentrations (Fig. 4). We varied the level of GALPPR1-1 expression by growing cells with different concentrations of galactose in the medium; levels of ura3-52 RNA confirmed that higher concentrations of galactose resulted in higher intracellular PPR $1^{c}$ protein concentrations (Fig. 4B). The results show that $U R A 3$ at the telomeric locus was less responsive to low levels of the trans-activator than URA3 at an internal locus (Fig. $4 \mathrm{~B}, \mathrm{C}$. In addition, although both loci can achieve the same maximum level of expression, a higher PPR $1^{c}$ concentration was required for the telomeric URA3 compared with the internal $U R A 3$ (Fig. $4 \mathrm{~B}, \mathrm{C}$ ). These results suggest that there is a competition for binding at the telomeric URA3 promoter between PPR $1^{\mathrm{c}}$ and silent chromatin.

$P P R 1^{c}$ activation of a telomeric URA3 gene is cell cycle regulated

The experiments described above were performed on ac-
A

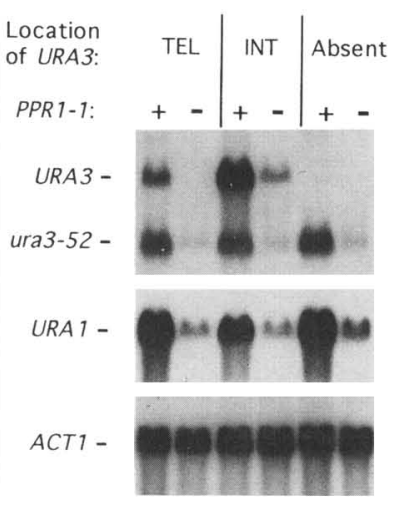

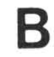

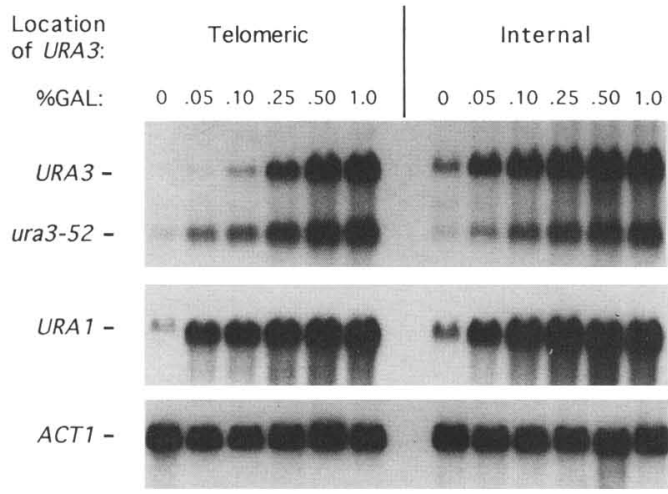

C

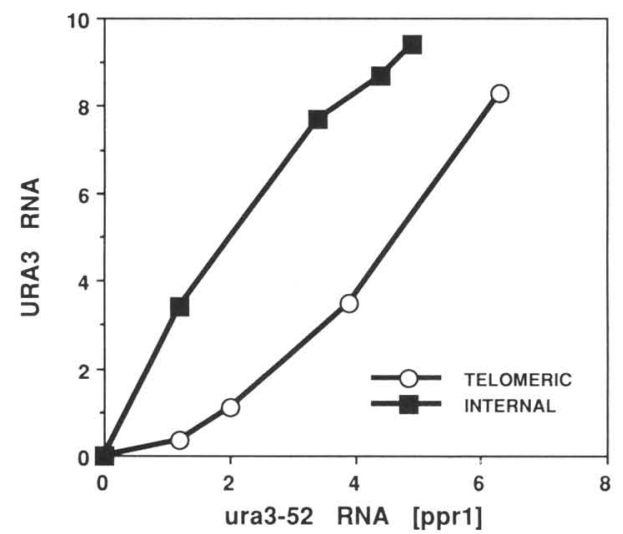

Figure 4. Modulating the dosage of $P P R 1^{c}$ reveals a competition for accessibility of the trans-activator to the telomeric $U R A 3$ gene. (A) RNA blot hybridization analysis of strains with URA3 at a telomeric (TEL) (UCC409, UCC410) or internal (INT) (UCC435, UCC436) chromosomal locus or absent (UCC433, UCC434), which had a GALPPR1-1 (PPR1-1: "+ ") or GALPpr1-1 (PPR1-1: -) gene fusion integrated at the leu2 locus. The normal PPR1 gene locus was deleted in all strains. Total RNA was isolated from cells grown in YEP-3\% raffinose $/ 0.3 \%$ galactose to induce expression of the GALPPR 1-1 gene fusions. The RNA was electrophoresed, blotted, and sequentially hybridized with the probes described in Fig. 1B, except that a URA3 DNA probe was used in this and subsequent figures. (B) RNA blot hybridization analysis of cells with the integrated GALPPR1-1 gene fusion and either a telomeric URA3 (UCC409) or an internal URA3 (UCC435), grown in YEP-3\% raffinose plus the indicated galactose concentration (\%GAL). The blot was hybridized with the probes described in $A$. $(C)$ The amount of probe hybridizing the RNA samples in $B$ was quantified. The ura3-52 and URA3 message levels were calculated relative to $A C T 1$, and the ura3-52 and URA3 values at $0 \%$ galactose (no PPR $1^{\mathrm{C}}$ ) were set as a background to zero. The level of ura3-52 message above the zero value is directly proportional to the in vivo level of active PPR 1 in each sample [pprl]. 
tively dividing cells. Hence, the cells were transiting through the cell cycle during the analysis. Keeping this in mind, two simple models can be set forth to explain the competition between PPR1 and telomeric chromatin for expression of the URA3 gene. In the first model, the competition only occurs within specific periods of the cell cycle. During part of the cell cycle the telomeric $U R A 3$ gene is resistant to activation by PPR1 if the silent chromatin state has been established. Only when the silent chromatin is weakened or disassembled, which might occur during DNA replication of the telomeric region, does PPR 1 have the opportunity to activate the gene. In the second model, PPR 1 competes with equal efficacy throughout the cell cycle.

To test and distinguish between these models, cells were grown in rich medium containing 3\% raffinose and no galactose. Thus, $P P R 1^{\mathrm{c}}$ was not present and the telomeric $U R A 3$ gene was maintained in a silent state. The cells were then synchronously arrested by treatment with either $\alpha$-factor pheromone, to arrest them late in $G_{1}$ (Pringle and Hartwell 1981), or nocodazole, an inhibitor of microtubule assembly (Pillus and Solomon 1986). In many eukaryotes, nocodazole produces a synchronous arrest at metaphase. Nocodazole also produces a very synchronous arrest in yeast; however it is unclear whether the arrest occurs late in $\mathrm{G}_{2}$ or at metaphase. By the criterion of spindle pole body separation, the cells appear to be in $\mathrm{G}_{2}$ (Jacobs et al. 1988); however, recent studies suggest that the chromosomes may be condensed as expected for a metaphase arrest (Guacci et al. 1994). In light of this uncertainty, we will refer to the arrest as $\mathrm{G}_{2} /$ metaphase. Once arrested, galactose was added to induce expression of $P P R 1-1$, and half of the culture was released from the arrest while arrest was maintained in the other half. Expression of the telomeric $U R A 3$ gene and the internal URA1 and ura3-52 genes was compared. The transcript levels of CLN2 and SWI5 were also analyzed to monitor the progress of cells through the cell cycle. CLN2 is transiently expressed in late $\mathrm{G}_{1}$ near the time of Start (Wittenberg et al. 1990), and SWI5 is transiently expressed beginning sometime in $S$, through $G_{2}$, and on into $M$ (Nasmyth et al. 1987).

The telomeric $U R A 3$ was not activated by PPR $1^{\circ}$ during $\alpha$-factor arrest (Fig. 5). The analysis clearly shows that while cells were arrested with $\alpha$-factor, the telomeric $U R A 3$ gene remained repressed. The increase in URA1 and ura3-52 mRNA levels indicates that PPR $1^{\mathrm{c}}$ was active in these cells. Following release from the $\alpha$-factor arrest, PPR $1^{\mathrm{c}}$ was able to activate the telomeric $U R A 3$ gene. The analysis of the SWI5 transcript (Fig. 5) and microscopic analysis of cell morphology (data not shown) were consistent with the cell-cycle arrest imposed by $\alpha$-factor and release thereafter. The low level of telomeric URA3 transcript seen late during the continued $\alpha$-factor arrest correlated with the small fraction of cells $(\sim 5 \%)$ that escaped from the arrest.

In striking contrast to the repressed state of telomeric $U R A 3$ during $\alpha$-factor arrest, the telomeric $U R A 3$ gene in $\mathrm{G}_{2}$ /metaphase, nocodazole-arrested cells was effectively activated by PPR $1^{\mathrm{c}}$ (Fig. 6). In the absence of func-

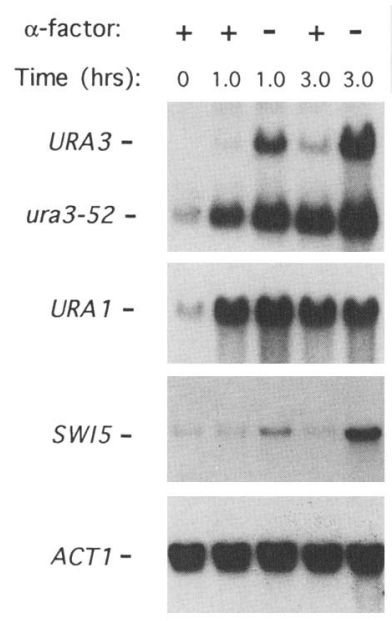

Figure 5. Silencing of a telomere-linked $U R A 3$ gene is not reversible while cells are arrested in late $G_{1}$ with $\alpha$-factor. Cells with a telomeric $U R A 3$ and the integrated GALPPR1-1 gene fusion (UCC409) were grown in YEP-3\% raffinose and arrested with $\alpha$-factor. When $>95 \%$ of the cells were arrested as unbudded cells, the culture was pelleted by centrifugation, and half of the culture $(\alpha$-factor: +$)$ was resuspended in medium containing $0.3 \%$ galactose and $\alpha$-factor, whereas the other half of the culture $(\alpha$-factor: $-\mid$ was resuspended in medium containing $0.3 \%$ galactose but lacking $\alpha$-factor; $t=0 \mathrm{hr}$. Aliquots of each culture were harvested to prepare RNA at the indicated times. The blot was hybridized with the probes described in Fig. 4A and with a SWI5 DNA probe.

tional PPR $1^{\mathrm{c}}$ (Fig. 6A, GALppr1-1), no activation of the telomeric $U R A 3$ or the internal URA1 and ura3-52 genes occurred. Not even basal expression of the telomeric $U R A 3$ was seen in the absence of PPR $1^{c}$. Analyses of CLN2 and SWI5 expression (Fig. 6), as well as microscopic analyses of cell morphology (data not shown), confirmed the successful arrest with nocodazole and the release that followed.

To determine whether the effects of the $\alpha$-factor and nocodazole treatments were attributable to the specific cell cycle arrests and not to other physiological effects of the treatments, we tested the effect of $\alpha$-factor on telomeric gene expression in cells arrested in $\mathrm{G}_{2}$ with nocodazole and, conversely, the effect of nocodazole on telomeric gene expression in cells arrested in $G_{1}$ with $\alpha$-factor. The $\alpha$-factor treatment did not prevent the expression of the telomeric URA3 gene in cells arrested previously with nocodazole, and nocodazole treatment did not result in expression of the telomeric gene in cells arrested previously with $\alpha$-factor (Fig. 6B). Thus, it appears that the effects on telomeric gene transcription by $\alpha$-factor and nocodazole were attributable to the specific cell cycle arrests. These results suggest that the ability of a trans-activator $\left(\mathrm{PPR}^{\mathrm{c}}\right)$ to function in a telomeric domain is cell cycle regulated. We propose that a transactivator is inaccessible to the telomeric domain in $\mathrm{G}_{1}$ phase and becomes accessible by the time the cells are in $\mathrm{G}_{2} /$ metaphase.

To more accurately determine the period of the cell cycle in which $P P R 1^{c}$ activation of a telomeric $U R A 3$ 

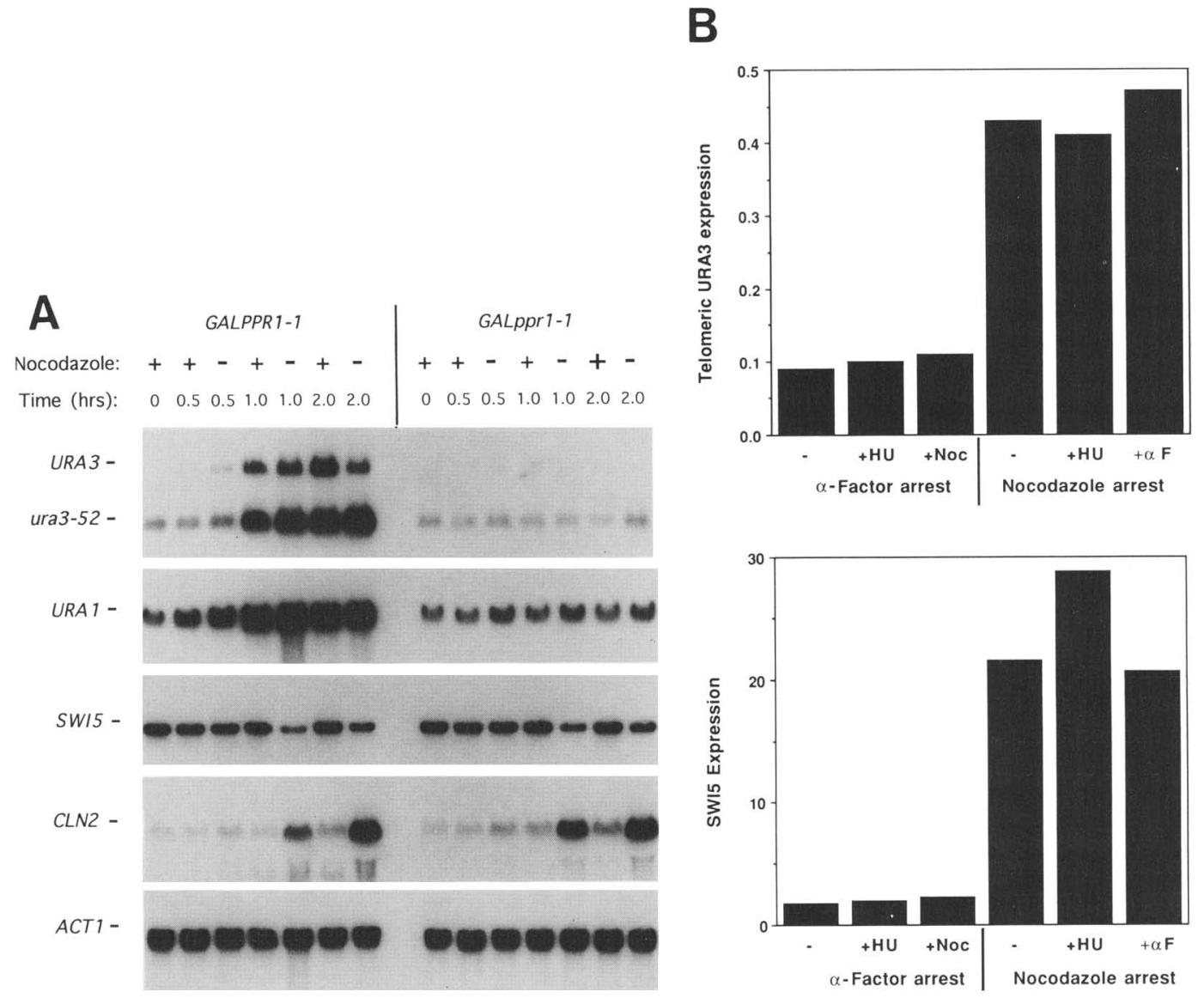

Figure 6. PPR1-1 can induce telomeric URA3 gene expression while cells are arrested with nocodazole. $(A)$ RNA blot hybridization analysis of telomeric URA3 expression in cells during and after arrest with nocodazole. Cells with URA3 adjacent to telomere VII-L, and the GALPPR1-1 (UCC409) or GALppr1-1 (UCC410) gene fusion integrated at the leu2 locus were grown in YEP-3\% raffinose and arrested with $\alpha$-factor. These presynchronized $G_{1}$ cells were released from the $\alpha$-factor arrest into medium containing nocodazole. Cultures were incubated with nocodazole until $>85 \%$ of the cells arrested as large budded cells. The cells were pelleted by centrifugation, and half of each culture was resuspended in medium containing galactose and nocodazole (Nocodazole: + , whereas the other half of each culture was resuspended in medium containing galactose but lacking nocodazole (Nocodazole: - ; this is $t=0 \mathrm{hr}$. Aliquots of each culture were harvested for RNA preparation at the indicated times. The blot was sequentially hybridized with the probes described in Fig. 5 and with a CLN2 DNA probe. $(B)$ Cells with a telomeric $U R A 3$ were arrested in $\mathrm{G}_{1}$ with $\alpha$-factor $(\alpha$-factor arrest) or in $\mathrm{G}_{2}$ /metaphase with nocodazole (Nocodazole arrest). Next, hydroxyurea (+HU), nocodazole (+ Noc), $\alpha$-factor (+aF), or nothing $(-\mid$ was added to the cultures while $\alpha$-factor arrest or nocodazole arrest was maintained. After $1 \mathrm{hr}$, galactose was added to all cultures to $0.3 \%$, incubation of the arrested cells was continued for $1 \mathrm{hr}$, and the cultures were harvested for RNA preparation. RNA blot hybridization analysis of the samples was carried out with the probes described in Fig. 5 and quantified. The ratio of telomeric $U R A 3$ to ura3-52 RNA is plotted as telomeric URA3 expression. The ratio of SWI5 to ACT1 mRNA is plotted below as SWI5 expression.

could occur, cells were arrested in S phase with hydroxyurea (HU), an inhibitor of DNA replication (Slater 1973). Yeast cells with a telomeric URA3 and the integrated GALPPR1-1 fusion were pregrown in medium lacking galactose, to maintain repression of the telomeric URA3 gene, and arrested with $\alpha$-factor. Galactose was added to the $\alpha$-factor-arrested cells to induce expression of PPR1-1, and the cells were released from the $\alpha$-factor arrest; half of the culture was released into medium containing HU. Cells treated with this $\alpha$-factor/ HU protocol arrest very early in $\mathrm{S}$ phase, significantly before telomeric regions replicate (Hartwell 1976; McCarroll and Fangman 1988). HU prevented the activation of the telomeric URA3 (Fig. 7) but did not affect transcriptional activation of the internal URA1 and ura3-52 genes (data not shown). Telomeric URA3 and $S W I 5$ expression following release from the HU arrest indicated that the arrest was reversible (Fig. 7, HU washout). Additionally, HU did not prevent activation of the telomeric $U R A 3$ gene in cells that were arrested previously in $\mathrm{G}_{2}$ /metaphase with nocodazole, indicating that the presence of $\mathrm{HU}$ itself does not prevent telomeric $U R A 3$ expression (Fig. 6B). These results indicate that early in $\mathrm{S}$ phase the trans-activator cannot gain access to the telomeric $U R A 3$ and, taken together with the results above, suggest that progression through $\mathrm{S}$ phase is required for the establishment of the transcriptionally active state in the telomeric domain. 

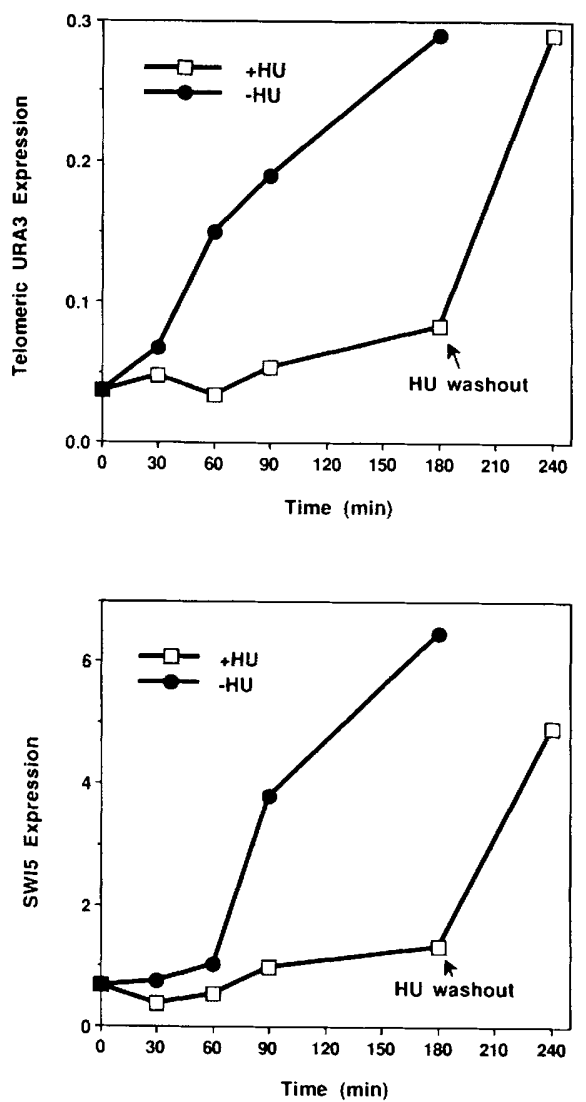

Figure 7. Silencing of a telomere-linked URA3 gene is not reversible while cells are arrested in early $S$ phase with HU. Cells with URA3 adjacent to telomere VII-L and the GALPPR1-1 gene fusion integrated at the leu2 locus (UCC409) were grown in YEP-3\% raffinose and arrested with $\alpha$-factor. Galactose was added to these presynchronized $G_{1}$-arrested cells; following a 45-min incubation with galactose, the cells were released from the $\alpha$-factor arrest into medium containing $\mathrm{HU}$ and galactose $(+\mathrm{HU})$, or into medium containing galactose but no $\mathrm{HU}(-\mathrm{HU})$ at $t=0 \mathrm{~min}$. The HU-treated culture was released from the arrest ( $t=180 \mathrm{~min}$ ) HU washout) and resuspended in medium containing galactose but no HU. Cells were collected for RNA isolation at the times indicated and subjected to RNA blot hybridization analysis with the probes described in Fig. 5. Hybridization was quantified, and the ratio of URA3 to ura3-52 RNA levels was plotted graphically as telomeric $U R A 3$ expression. Expression of SWI5 was standardized to the level of ACT1 expression and plotted graphically as SWI5 expression.

Temperature-sensitive alleles of $C D C$ (cell division control) genes represent another method commonly used to arrest yeast cells at a specific point in the cell cycle (Pringle and Hartwell 1981). Cells are typically shifted from a permissive growth temperature $\left(-23^{\circ} \mathrm{C}\right)$ to a nonpermissive temperature $\left(37^{\circ} \mathrm{C}\right)$ to cause arrest. We began to use temperature-sensitive alleles of $C D C$ genes to define the cell cycle period in which PPRl activation occurred. However, we discovered that PPR $1^{\mathrm{c}}$-induced expression of a telomeric $U R A 3$ was compromised severely at $37^{\circ} \mathrm{C}$ in wild-type $\left(C D C^{+}\right)$cells (Aparicio 1993). This finding precluded our use of temperature-sensitive al- leles in dissecting the period of activation in the cell cycle. The effect appeared to be telomere specific, because the ura3-52 locus was activated. It is not clear whether the effect of temperature on telomeric URA3 activation was specific to PPR $1^{\circ}$ (e.g., a reduction in the effective concentration of PPR $1^{c}$ ) or whether it reflects a general strengthening of telomeric repression (e.g., the silent state was assembled more rapidly at $37^{\circ} \mathrm{C}_{i}$ see Discussion).

\section{Telomeric silencing is irreversible when cells are} in stationary phase $\left(G_{0}\right)$

An additional means to synchronously arrest a population of yeast cells is to maintain a culture in stationary phase (for review, see Werner-Washburne et al. 1993). Stationary-phase cells of $S$. cerevisiae arrest in a state referred to as $G_{0}$; the cells are unbudded and their genomes are unreplicated. Cells enter $G_{0}$ by exiting from $G_{1}$ phase, and general transcriptional repression occurs upon entry to stationary phase (Choder 1991). Strains with $U R A 3$ at a telomeric or a nontelomeric locus and an integrated GALPPR1-1 were grown to stationary phase in rich medium containing $3 \%$ raffinose, so that PPR $1^{\mathrm{c}}$ was absent and, hence, the telomeric $U R A 3$ gene was silenced. Cells were determined to be in stationary phase when the optical density of the culture had not increased during the previous $24-\mathrm{hr}$ period, and $>98 \%$ of cells were unbudded. Expression of GALPPR1-1 was induced in the stationary cells by adding $0.3 \%$ galactose to the cultures. Incubation was continued as aliquots were collected for RNA analysis. Although the internal URA3 gene, as well as the URA1 and ura3-52 genes, was transcriptionally activated by $P P R 1^{c}$ in the stationary cells, the telomeric $U R A 3$ gene was not activated (Fig. 8). Only after $48 \mathrm{hr}$ of induction was a telomeric $U R A 3$ transcript observed, just slightly above limits of detection (Fig. 8). Thus, silencing of a telomeric gene in stationary-phase cells is essentially irreversible. As expected, basal levels of transcription decreased in the stationary cells (Fig. 8, cf. uninduced URA1 levels in the stationary and log cells|. Moreover, the SWI5 transcript was not detected in $\mathrm{G}_{0}$ cells, confirming that cells were not progressing through the mitotic cell cycle. In the experiment shown here, galactose was added to cultures $\sim 48 \mathrm{hr}$ after midlog phase; equivalent results were obtained when the experiment was performed with 7-day-old cultures (data not shown).

\section{Discussion}

In this study we examined the ability of trans-activator proteins to overcome silencing of a telomere-adjacent gene in $S$. cerevisiae. We found that the trans-activator protein PPR1 is absolutely required for expression of a URA3 gene located immediately adjacent to the left telomere of chromosome VII (Fig. 1). In contrast, when $U R A 3$ is at a nontelomeric location, PPR1 merely pro- 


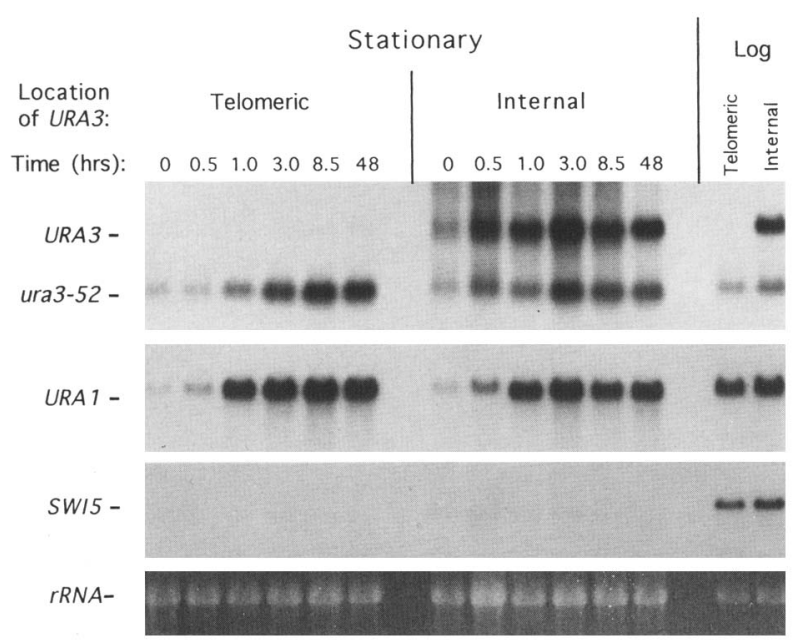

Figure 8. Silencing of a telomere-linked $U R A 3$ gene is not reversible in stationary-phase cells. Strains with a telomeric (UCC409) or an internal (UCC435) URA3 gene and the integrated GALPPR 1-1 gene fusion were grown in YEP-3\% raffinose into stationary phase. Galactose was added to both cultures to $0.3 \%(t=0 \mathrm{hr})$, and aliquots were harvested for RNA preparation at the indicated times. The percentage of unbudded cells in the cultures remained above $98 \%$ at each time point. Ethidium bromide staining of the 18S rRNA in the gel prior to transfer is shown. RNA isolated from uninduced cells of the same strains during logarithmic growth in YEP-3\% raffinose (no galactose) were included at the far right as controls for SWIS expression. The blot was analyzed with the same probes described in Fig. 5.

vides a modest increase in expression (Roy et al. 1990, Fig. 1). Two conclusions may be drawn from these results: (1) Telomeres inhibit basal transcription; and (2) trans-activators have a mechanism to circumvent this inhibition.

It is likely that the basal transcription apparatus of $U R A 3$ is prevented from accessing the gene's promoter because of steric occlusion by silent telomeric chromatin. This notion is supported by the observation that other DNA-binding proteins, such as $E$. coli dam methylase, are excluded from telomere-proximal DNA regions in vivo (Gottschling 1992). Note that basal expression of $U R A 3$, as with most housekeeping genes in yeast, requires not only a TATA element but additional sequences upstream that bind PPR 1-independent factors (Roy et al. 1990).

Although it is unclear how PPRl or any other transactivator protein activates transcription, several of our results address the mechanism of overcoming silencing. First, PPR1 cannot activate transcription of the telomeric $U R A 3$ gene in $\mathrm{G}_{1}$, early $\mathrm{S}$, or $\mathrm{G}_{0}$ cells. Only in a $\mathrm{G}_{2} /$ metaphase arrest is activation observed (Figs. 5-8). Second, the cellular concentration of PPR1 dramatically affects the frequency with which telomeric URA3 expression is established (Figs. 1, 2, and 4). Third, the complete activation domain of a trans-activator is essential for its efficacy (Fig. 3). Although a telomeric gene with a
GAL4 UAS can be activated in the presence of wild-type $G A L 4$, the gene remains silenced when the wild-type GAL4 is replaced by derivatives that remove the GAL4 transcriptional activation domain.

On the basis of our results, we propose a replicationdependent model (see introductory section) to explain how a telomeric gene can overcome silencing to become transcriptionally active. In $G_{1}$ of the cell cycle, a silenced telomeric gene is packaged in a repressive chromatin structure that is relatively "static" and prevents interactions of the DNA with other DNA-binding proteins such as basal transcription factors and trans-activators. However, the telomeric chromatin loses its static structure as a result of the DNA replication process or some other coordinate cellular event. Alternatively, one of the two newly replicated sister chromatids retains the silent chromatin, whereas the other is essentially "naked" DNA and awaits assembly into chromatin. Regardless of which pathway occurs, upon completion of replication, two distinct assembly processes compete to establish the transcriptional state of a telomeric gene. Assembly of silent chromatin initiates at the telomere and propagates inward along the DNA. This process not only requires the histones but a number of additional factors, such as RAP1, SIR2, SIR3, and SIR4 (Aparicio et al. 1991; Kyrion et al. 1993). The competing process involves the binding of the trans-activator protein to the telomeric gene and assembly of an active transcription complex. The competition ends when one of the two processes is fully established at the promoter region of the telomeric gene. In the absence of competition from the trans-activator, the silent chromatin eventually assembles into its static structure. The moment that this silent structure forms defines the end of the cell cycle period in which the trans-activator has an opportunity to compete. Although our results identify the existence of a cell cycle "window" for silent chromatin assembly, definition of its precise beginning and end awaits a more detailed analysis.

Having a limited period in the cell cycle during which a transcriptional state is established has several ramifications. Environmental or genetic changes that alter the duration of the silent chromatin assembly process could dramatically affect the frequency of establishing a state. Such changes may be direct. For instance, the SIR3 gene product appears to be a component of silent chromatin that is rate limiting in its assembly (Johnson et al. 1990; Renauld et al. 1993). Thus, increasing SIR3 concentration increases the frequency of establishing repression (Renauld et al. 1993). Alternatively, changes that extend periods of the cell cycle in which silent chromatin assembly occurs, such as $G_{2}$, provide a trans-activator greater opportunity to establish an active state. Conversely, a shorter $G_{2}$ would favor establishment of a silent state. In essence, such changes can dictate the amount of phenotypic variegation within a population of cells.

The assembly of silent telomeric chromatin may consist of several distinct, sequential steps rather than an "all-or-none", concerted process. Evidence for this suggestion comes from Figure 6A. In nocodazole-arrested 
cells, telomeric $U R A 3$ expression was rapid when PPR 1 was present (GALPPR1). However, basal or PPR1-independent (GALppr1) expression of the telomeric URA3 was not detected, even after a lengthy arrest $(\sim 5 \mathrm{hr})$, whereas basal expression at internal loci was normal. These results suggest that at the nocodazole-arrest point silent chromatin is assembled up to a stage that precludes basal expression yet does not prevent PPR1-induced expression. This postulated intermediate of silent chromatin assembly may not be locked into a fully static structure, yet it is still more recalcitrant to gene expression than other areas of the genome. The static chromatin structure likely requires several contributions: binding of the core histones by accessory proteins such as SIR3 (Renauld et al. 1993); modifications of telomeric histones such as hypoacetylation (Braunstein et al. 1993); and localization of the structure to the nuclear periphery (Palladino et al. 1993). Any of these contributions may be absent at an intermediate stage. Thus, we propose that the system defined here will be very useful in examining the assembly steps of silent chromatin in vivo.

Our results both complement and extend observations made at the yeast silent mating type loci $H M L$ and $H M R$ (Miller and Nasmyth 1984). Telomeres and the HM loci share a number of silencing factors (e.g., SIR2, SIR3, and SIR4) (Aparicio et al. 1991). Using temperature-sensitive alleles of SIR3 and SIR4, Miller and Nasmyth determined that establishment of silencing at the $H M$ loci requires passage through $S$ phase and, thus, presumably DNA replication. Their conclusion is consistent with the model we propose, that the competition for assembly occurs after replication. Furthermore, we show that at least in the case of the VII-L telomeric locus, assembly of silencing is not completed until sometime after $\mathrm{G}_{2} /$ metaphase (nocodazole arrest). In their experiments, Miller and Nasmyth also found that inactivating the SIR3 or SIR4 gene product at any time in the cell cycle resulted in gene expression at the $H M$ lsci. Here, we show that passage through $S$ phase is required for activation of a telomeric gene. Thus, dismantling of the repressive chromatin, either by artificially compromising it with a defective SIR3 or SIR4 allele, or in every cell cycle during passage through $S$ phase, allows a renewal of the competition between establishment of active and silent states.

As the result of a telomeric location, URA3 can be much more highly regulated than at its normal locus. When URA3 is at a nontelomeric location, the presence of PPR $1^{\mathrm{c}}$ produces a three- to sevenfold induction over basal expression (Liljelund et al. 1984; Fig. 4B). However, with URA3 near a telomere, an equivalent amount of PPR 1 induces expression $\sim 100$-fold (Fig. $4 B$ ). We suggest that eukaryotic genomes may have evolved to take advantage of this type of telomeric regulation. For example, trypanosomes depend on the highly regulated expression of the telomeric VSG (variable surface glycoprotein) genes (for review, see Borst 1991; Cross 1990).

When cells were in $\mathrm{G}_{0}$, essentially no amount of transactivator protein was sufficient to overcome telomeric silencing, whereas at an internal nonsilenced position the trans-activator readily induced expression (Fig. 8). Interestingly, general transcriptional repression, apparently mediated by chromatin changes, occurs upon entry to stationary phase (Choder 1991). Stationary-phase chromosomes display different sedimentation properties than $G_{1}$-phase chromosomes, suggesting that chromosomes assume a distinct compact structure in $G_{0}$ cells (Piñon 1978). It is possible that the same machinery and mechanism of telomeric silencing in $G_{1}$ extends to other regions of the genome in $G_{0}$, thus facilitating the more global compaction and transcriptional repression.

Whatever the nature of the silent telomeric chromatin, it contrasts with the chromatin structure of the PHO5 gene in yeast. Although this locus is transcriptionally repressed by nucleosomes upstream of the transcription initiation site, it can be induced rapidly at anytime in the cell cycle or in $\mathrm{G}_{0}$-arrested cells / $\mathrm{Schmid}$ et al. 1992). The induction involves the displacement of a nucleosome by the gene's transcriptional activator protein. In contrast, overcoming telomeric silencing requires that the nucleosomes be modified or removed by passage through $\mathrm{S}$ phase before the trans-activator protein can have its effect. This emphasizes that telomeric chromatin is inherently different than chromatin at PHO5 or most other regions of the yeast genome.

In an attempt to understand telomere position-effect variegation, we have examined one aspect of this phenomenon: the ability of a telomeric gene to switch from a silent to an expressed state. Our findings have provided insights into the cell cycle-regulated nature of the silent state, the establishment of an active state, and the realization that the establishment process must recur each time a cell replicates its genome. We expect that the study of telomere position effect as presented here will serve as a model system for understanding the process of chromatin assembly in vivo. In addition, it will assist us in understanding the role of chromatin in propagating a phenotypic state through successive cell generations.

\section{Materials and methods}

Plasmid constructions

Plasmid FAT-PPR 1 was constructed by ligating a 4.4-kb EcoRI fragment containing the PPR1 gene (from pUC8-PPR1, a gift from R. Losson, CNRS, Strasbourg, France) into plasmid YEpFAT10 (referred to as "FAT" in the legend to Fig. 2 and in text), $[2 \mu$ ARS, TRP1, leu2-d, a gift from K. Runge (Runge and Zakian 1989)]. A $3.7-\mathrm{kb}$ HindIII-SphI fragment containing the entire PPR1-1 allele [from plasmid pFL11 (Losson and Lacroute 1983)] was inserted into plasmid pVZ1 (Henikoff and Eghtedarzadeh 1987). The resulting plasmid (pVZPPR1-1) provided a $3.7-\mathrm{kb}$ HindIII-BamHI fragment containing PPR1-1 that was ligated into pRS425 (Sikorski and Hieter 1989) to yield plasmid pRS4-PPR1-1. Plasmids pRS305-GALPPR1-1 and pRS305GALppr1-1 were constructed in a series of steps. A 685-bp EcoRI-BamHI fragment containing the GAL1,10 promoter [from pBM150, (Johnston and Davis 1984)] was ligated into EcoRI-BamHI-digested pRS314 (Sikorski and Hieter 1989); the resulting plasmid (pRS314GAL) was digested with ApaI-EcoRI, and a 2.8-kb ApaI-EcoRI fragment containing the $3^{\prime}$ portion of PPR1-1 from plasmid pRS4-PPR1-1 was inserted yielding pRS3GAL3'PPR1-1. Next, a 500-bp fragment containing the $5^{\prime}$ 
portion of the PPR1-1 allele was produced by PCR amplification (Innis et al. 1990). The primers were designed to introduce an EcoRI site 28 bp upstream of the PPR1 ATG initiation codon and to include the EcoRI site within the PPR1-1-coding sequence (PPR1-ATG oligonucleotide, 5'-CCGGAATTCATACGAAGATGATGATTAAATC-3', the new EcoRI site is underlined; PPR1-n650 oligonucleotide, 5'-GGCTTGCCATAGACTTGCTCG-3'). The fragment was digested with EcoRI and inserted between the GAL1,10 promoter and the 3' PPR1-1 sequence in pRS3GAL3'PPR1-1; one orientation of the insert yielded pGALPPR1-1, which has the GAL1,10 promoter fused to the entire PPR1-1-coding sequence (GALPPR1-1), whereas the other orientation of the insert yielded pGALppr1-1, which has the $5^{\prime}$ portion of the PPR1-1 allele inverted resulting in a mutated gene fusion (GALppr1-1). The 3.5-kb ApaI-BamHI fragments containing GALPPR1-1 and GALppr1-1 from pGALPPR 1-1 and pGALppr1-1, respectively, were inserted into pRS305 (Sikorski and Hieter 1989) yielding pRS305-GALPPR1-1 and pRS305-GALppr1-1.

Plasmid pVZADH4 contains the $A D H 4$ locus on a $3.1-\mathrm{kb}$ EcoRI-SalI fragment (Gottschling et al. 1990). A 4.8-kb HindIII$X b a$ I fragment containing the LYS2 gene from plasmid pDP6 (Fleig et al. 1986) was inserted into XbaI-HindIII-digested pVZADH4 creating pVZadh4::LYS2. The $U A S_{G A L}-U R A 3$ allele was produced by sequential PCR amplification steps (Ausubel et al. 1989). The primers were designed to replace the PPRI binding-site [UAS $\mathrm{URA}_{\mathrm{URA}}$ 5'-TTCGGTAATCTCCGAA-3' (Roy et al. 1990)] with a GAL4-binding site [URA3-GAL-5' oligonucleotide, 5 '-CGGACGACTGTCGTCCGTCAAAAAAATTTCAAGGAAACCG, URA3-GAL-3' oligonucleotide, 5' -CGGACGACAGTCGTCCGCAGAAGGAAGAACGAAGGAA; the GAL4binding sequence is underlined (Verdier 1990)]. The $U A S_{G A L^{-}}$ $U R A 3$ PCR product was digested with Sall and BamHI and inserted into pRS315 $\left(-P_{s t} \mathrm{I}\right)$ producing pRS315(-PstI)-GALURA3; the PstI site in pRS315 was deleted previously by digestion of pRS315 (Sikorski and Hieter 1989) with PstI, making the ends blunt with T4 DNA polymerase, and religating the plasmid. Plasmid pRS315(-PstI)-GALURA3 was digested with HindIII and SmaI and religated, resulting in the $U A S_{G A L^{-}} U R A 3$ fragment being inverted in the vector to yield pRS315(-PstI)GALURA3-flip. This plasmid provided a 1.1-kb HindIII-BamHI fragment containing $U A S_{G A L}-U R A 3$, which was inserted into pVII-L URA3-TEL (Gottschling et al. 1990) to produce pADH4GALURA3TEL; the same 1.1-kb HindII-BamHI UAS$G A L^{-U R A 3}$ fragment was inserted into HindIII-BamHI-digested pVZADH4 resulting in plasmid p $\Delta$ adh4::GALURA3. A $1.2-\mathrm{kb}$ HindIII-NotI fragment (made blunt-ended with T4 DNA polymerase, from pVII-L URA3-TEL) was ligated into HindIII (made blunt-ended with T4 DNA polymerase) digested pVZadh4::LYS2 producing pURA3-TEL-LYS2. A 1.5-kbp PstI fragment (from pADH4GALURA3TEL) containing the UAS$G A L^{-} U R A 3$ promoter was inserted into PstI-digested pURA3TEL-LYS2 to replace the wild-type URA3 promoter; the resulting plasmid was pGALURA3-TEL-LYS2.

A $1.35-\mathrm{kbp}$ BamHI fragment containing the entire URA1 gene (Roy 1992) produced by PCR amplification of genomic DNA $15^{\prime}$ URA1 oligonucleotide, 5'-CGAACGGATCCCCTTCAGCCACTACAGCCTACTT-3'; 3'URA1 oligonucleotide, 5'CGAAGGGATCCGCCAATTGCGAATGCACTCACCG- ${ }^{\prime}$, the $B a m H I$ sites are underlined) was inserted into pVZl to yield plasmid pVZURA1. A 1.1-kb HindIII-BamHI URA3 fragment was ligated into HindIII-BamHI-digested plasmid YDpK (Berben et al. 1991), yielding plasmid YDpK-URA3. Plasmid p5'URA3 contains a 415-bp HindIII-EcoRV 5' URA3 fragment ligated into HindIII-EcoRV-digested pVZ1. Plasmid CY807 + TRP1 (bar1::TRP1) was constructed by inserting a 723- bp BamHI fragment containing TRP1, from YDp-W (Berben et al. 1991), into the BglII site in the BAR1 sequence in plasmid CY807 (from S. Honigberg, Syracuse University, NY). Plasmids pBM292 (GAL4-wild type, 881 amino acids), pBM430 (GAL4, carboxy-terminal amino acid 292), pBM433 (GAL4, carboxy-terminal amino acid 684), pBM789 (GAL4, carboxy-terminal amino acid 174), and pBM1268 (GAL4, carboxy terminal amino acid 383 ) are CEN, TRP1 plasmids described previously and provided by M. Johnston and Dover (1988). Plasmids pBD57 and pJM206 were provided by F. Cross (Rockefeller University, New York |, and plasmid pPL9 was provided by R. Surosky (Surosky and Esposito 1992).

Methods for DNA manipulation were described previously (Renauld et al. 1993).

\section{Yeast methods and strains}

S. cerevisiae were grown at $30^{\circ} \mathrm{C}$; liquid cultures were agitated during incubation at 180 RPM. All experiments in liquid culture were carried out with mid-log-phase cells unless otherwise indicated. Plating efficiency analysis and synthetic media have been described previously (Gottschling et al. 1990), except for $\alpha$-aminoadipate-containing medium, which was prepared as described in (Sikorski and Boeke 1991). Experiments involving galactose control employed YEP- $3 \%$ raffinose, and $0.3 \%$ galactose for induction unless otherwise indicated. For experiments involving drug or $\alpha$-factor washout, cells were pelleted by centrifugation for $3 \mathrm{~min}$ at $1500 \mathrm{~g}$ and washed and/or resuspended in prewarmed medium $\left(30^{\circ} \mathrm{C}\right)$. Cells were arrested with $20 \mathrm{nM}$ $\alpha$-factor for $3 \mathrm{hr}$, and $50 \mathrm{~mm}$ pthalic acid (pH 5.5) was included in the medium. For release from $\alpha$-factor arrest, $1 \mathrm{mg} / \mathrm{ml}$ of pronase $\mathrm{E}$ was included in the fresh resuspension media, except for the experiment described in Figure 6, where one water wash of the pellet was carried out and pronase $E$ was not included in the resuspension medium. Cells were arrested with $10 \mu \mathrm{g} / \mathrm{ml}$ of nocodazole (from a $1000 \times$ stock solution in dimethylsulfoxide) for $3 \mathrm{hr}$. HU was dissolved directly in medium immediately before use to a final concentration of $400 \mathrm{~mm}$, except in the experiments described in Figure 6B, where it was dissolved directly in the cultures. Cells were fixed and stored in $10 \mathrm{~mm}$ Tris- $\mathrm{HCl}, 100 \mathrm{mM}$ EDTA, $(\mathrm{pH} 8.0)$, and $3.7 \%$ formaldehyde and sonicated before microscopy to assess cell morphology.

$S$. cerevisiae were transformed using the lithium acetate procedure (Ito et al. 1983). The URA3 gene was placed adjacent to the telomere sequence $\left(\mathrm{TG}_{1-3}\right)_{\mathrm{n}}$ on the left end of chromosome VII (UCC2013) or inserted at the $A D H 4$ locus about $20 \mathrm{~kb}$ from the telomere on VII-L (UCC432), as described previously (Gottschling et al. 1990). UCC2013 was derived from YPH499 (see Table 1), and UCC432 was derived from UCC431 (described below).

Strains UCC111, UCC113, UCC115, UCC412, and UCC2014 were constructed by transformation of strains UCC1001, UCC1003, YPH250 (see Table 1), UCC411 (described below), and UCC2013 respectively, with plasmid p $\triangle P P R 1:: H I S 3$ and selection for $\mathrm{HIS}^{+}$transformants; this plasmid has been described previously (Renauld et al. 1993). Strains UCC116, UCC117, and UCC151 were derived from strains UCC1001, UCC1003, and YPH250, respectively, by transformation with plasmid pFAT-PPR 1 and selection for $\mathrm{TRP}^{+}$cells; strains UCC238, UCC152, and UCC153 were derived from strains UCC1001, UCC1003, and YPH250, respectively, by transformation with plasmid YEpFAT10 (FAT) and selection for TRP ${ }^{+}$.

Strain UCC411 was derived from YPH499 by transformation with HpaI-digested YDpK-URA3 and selection for LYS ${ }^{+}$cells. UCC413 and UCC2016 were derived from UCC412 and UCC2014, respectively, by transformation with plasmid CY807+TRP1-digested with ClaI. Strain UCC431 was a 
Table 1. Genotypes and sources of strains

\begin{tabular}{|c|c|c|}
\hline Strain & Genotype & Source \\
\hline YPH250 & 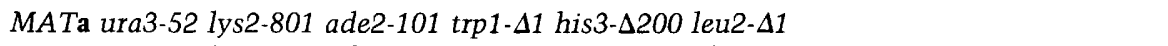 & (Sikorski and Hieter 1989) \\
\hline YPH499 & MATa ura3-52 lys2-801 ade2-101 trp1- 463 his3- $\Delta 200$ leu2- $\Delta 1$ & (Sikorski and Hieter 1989) \\
\hline YM725 & MATa ura3-52 lys2-801 ade2-101 trp1-901 his3-200 tyr1-501 met- can1 gal4-542 gal80-538 & (Johnston and Dover 1988) \\
\hline UCCl001 & YPH250 URA3-TEL-VII-L & (Gottschling 1992) \\
\hline UCC1003 & YPH250 adh4::URA3 & (Renauld et al. 1993) \\
\hline $\mathrm{UCC} 111$ & UCC1001 ppr14::HIS3 & this study \\
\hline $\mathrm{UCCl} 13$ & UCCl003 ppr1 $1:: H I S 3$ & this study \\
\hline $\mathrm{UCCl} 15$ & YPH250 ppr1 $1:: H I S 3$ & this study \\
\hline UCC419 & YM725 adh4::UAS $S_{G A L}-U R A 3$ & this study \\
\hline UCC420 & YM725UAS $S_{G A L}-U R A 3-T E L-V I I-L$ & this study \\
\hline UCC409 & YPH499 ppr1 $\triangle:: H I S 3$ bar1::TRP1 URA3-TEL-VII-L leu2::GALPPR1-1::LEU2 & this study \\
\hline UCC410 & YPH499 ppr1 $\triangle:: H I S 3$ bar1::TRP1 URA3-TEL-VII-L leu2::GALPPR1-1::LEU2 & this study \\
\hline UCC433 & YPH499 ppr1 $\triangle:: H I S 3$ bar $1:: T R P 1$ leu2::GALPPR1-1::LEU2 & this study \\
\hline UCC434 & YPH499 ppr1 $\Delta:: H I S 3$ bar1::TRP1 leu2::GALPPR1-1::LEU2 & this study \\
\hline UCC435 & YPH499 ppr1A::HIS3 bar1::TRP1 adh4::URA3 leu2::GALPPR1-1::LEU2 & this study \\
\hline UCC436 & YPH499 ppr1A::HIS3 bar1::TRP1 adh4::URA3 leu2::GALPPR1-1::LEU2 & this study \\
\hline
\end{tabular}

5-FOA ${ }^{\mathrm{R}}$ (Ura $^{-}$, Lys $^{-}$) derivative of UCC413. Strains UCC409, UCC433, and UCC435 were derived from strains UCC2016, UCC431, and UCC432 respectively, by transformation with HpaI-digested pRS305-GALPPR1-1; strains UCC410, UCC434, and UCC436 were derived from strains UCC2016, UCC431, and UCC432, respectively, by transformation with $\mathrm{HpaI}$ digested pRS305-GALppr1-1.

To place $U A S_{G A L}-U R A 3$ (or another nonselectable marker) adjacent to telomere VII-L, a method was developed based on the phenomenon of new telomere formation at internal telomeric sequences (Gottschling et al. 1990). Plasmid pGALURA3TEL-LYS2 was used to integrate within the ADH4 locus: UAS$G A L-U R A 3$ adjacent to 81 bp of telomere repeat sequence followed by LYS2 as the selectable marker (centromere-proximal to centromere-distal). At a frequency of $\sim 10^{-6}$, loss of chromosomal sequences distal to the 81-bp internal telomeric sequence (including LYS2) resulted in formation of a new and stable telomere having the $U A S_{G A L}-U R A 3$ gene adjacent to it (data not shown). Cells that were transformed with pGALURA3-TELLYS2, and were $\mathrm{LYS}^{+}$and had the correct sequences inserted within the $A D H 4$ locus /verified by DNA blot hybridization analysis), were grown nonselectively for $\sim 25$ generations. Cells that had lost LYS2 were selected for survival on medium containing $\alpha$-aminoadipate; the expected structure of telomere VII-L in the resulting Lys ${ }^{-}$strain was verified by DNA hybridization analysis. UCC418 was derived from YM725 (see Table 1) by transformation with NotI-SalI-digested plasmid pGALURA3-TEL-LYS2 and selection for LYS $^{+}$transformants; UCC 420 was an $\alpha$-aminoadipate resistant $\left(\mathrm{Lys}^{-}\right)$derivative of UCC418 that has $U A S_{G A L}-U R A 3$ adjacent to telomere VII-L. UCC419 was derived from YM725 by transformation with EcoRI-SalI-digested plasmid p $\Delta$ adh4::GALURA3 and selection for URA ${ }^{+}$transformants. Strains UCC419 and UCC420 were transformed with plasmids pBM292, pBM430, pBM433, pBM789, and pBM1268, to yield strains UCC421-UCC425, respectively, for the UCC419 parent, and strains UCC426UCC430, respectively, for the UCC420 parent. The expected structures of the various chromosomal constructs were confirmed by DNA blot hybridization analysis (data not shown).

Analysis of nucleic acids

Methods for DNA preparation and analysis have been described previously (Gottschling et al. 1990).

RNA was isolated from mid-log-phase cells, unless otherwise indicated, as described previously (Gottschling et al. 1990). RNA hybridization analyses were performed as described previously (Gottschling et al. 1990), except that 15 or $20 \mu \mathrm{g}$ of total RNA was denatured in the presence of $20 \mu \mathrm{g} / \mathrm{ml}$ of ethidium bromide and separated by electrophoresis on a $1.2 \%$ agarose$5 \%$ formaldehyde ( $37 \%$ stock)-MOPS gel. Immediately following electrophoresis the gel was photographed and washed twice for $15 \mathrm{~min}$ in $\mathrm{H}_{2} \mathrm{O}, 15 \mathrm{~min}$ in $10 \times \mathrm{SSC}$ and transferred to nylon (Micron Separations, Inc., Westboro, MA). Photography of the gel following transfer verified that complete transfer of the rRNA had occurred. RNA was immobilized on the nylon membrane by UV irradiation (120 mJ) of the damp membrane, followed by prehybridization of the membrane. Prehybridization and hybridization solutions contained $5 \times$ SSC, $50 \%$ formamide, $5 \times$ Denhardt's solution, $0.2 \mathrm{mg} / \mathrm{ml}$ of denatured and degraded herring sperm DNA, $0.2 \%$ SDS; hybridization solution also contained $10 \%$ dextran sulfate, and was filtered through a 45- $\mu \mathrm{m}$ membrane to remove particulates. Prehybridization (1-6 $\mathrm{hr}$ ) and hybridization $(18-30 \mathrm{hr})$ were carried out at $42^{\circ} \mathrm{C}$ for DNA probes and $53^{\circ} \mathrm{C}$ for RNA probes. Blots were washed 5 min at $23^{\circ} \mathrm{C}$ in $2 \times$ SSC, $0.1 \%$ SDS, followed by two 15 -min washes at $55^{\circ} \mathrm{C}$ in $0.1 \times \mathrm{SSC}, 0.1 \% \mathrm{SDS}$ for DNA probes, or three $20 \mathrm{~min}$ washes at $60^{\circ} \mathrm{C}$ in $0.1 \times \mathrm{SSC}, 0.1 \%$ SDS for RNA probes, and exposed to film. The relative levels of URA3 and URA1 RNAs were quantified on a Radioanalytic Imaging System (Ambis, San Diego, CA). For rehybridization experiments, probes were removed from the blots with three 20 -min washes with boiling $0.2 \%$ SDS.

RNA antisense probes were labeled with $\left[{ }^{32} \mathrm{P}\right] \mathrm{CTP}$ or [ $\left.{ }^{32} \mathrm{P}\right] \mathrm{UTP}(3000 \mathrm{Ci} / \mathrm{mmole})$ by in vitro transcription of linearized plasmids with T7 RNA polymerase or SP6 RNA polymerase (Sambrook et al. 1989). DNA probes were labeled with [ $\left.{ }^{32} \mathrm{P}\right] \mathrm{dCTP}$ ( $3000 \mathrm{Ci} / \mathrm{mmole}$ ) by random oligonucleotide priming as described (Sambrook et al. 1989). Plasmid p5'URA3 (T7) was the template for the URA3 RNA probe. Plasmid pPL9 (SP6) was the template for the $A C T 1$ RNA probe. The URA3 DNA probe was a $1.1-\mathrm{kb}$ HindIII fragment containing the entire coding sequence, the URA1 probe was a $1.3-\mathrm{kb}$ BamHI fragment containing the entire $U R A 1$ gene in plasmid pVZURAl, the $S W I 5$ probe was a 3.3-kb HindIII fragment from pBD57, and the CLN2 probe was a $640-$ bp HindIII-SpeI fragment in pJM206.

\section{Acknowledgments}

We thank G. Berben, F. Cross, S. Honigberg, M. Johnston, R. 
Losson, R. McCarroll, K. Runge, and R. Surosky for providing plasmids and/or yeast strains, and B. Berg, H. Renauld, M. Singer, and J. Stevenson for comments on the manuscript. This work was supported by a National Science Foundation Predoctoral Fellowship and a William Rainey Harper Fellowship to O.M.A., and a Pew Charitable Trust Biomedical Scholars Fellowship and National Institutes of Health grant GM43893 to D.E.G.

The publication costs of this article were defrayed in part by payment of page charges. This article must therefore be hereby marked "advertisement" in accordance with 18 USC section 1734 solely to indicate this fact.

\section{References}

Aparicio, O.M. 1993. "Telomeric position effect in S. cerevisiae: A model for the establishment of alternative transcriptional states under epigenetic control," Ph.D. thesis. The University of Chicago, Chicago, Il.

Aparicio, O.M., B.L. Billington, and D.E. Gottschling. 1991. Modifiers of position effect are shared between telomeric and silent mating-type loci in S cerevisiae. Cell 66: 12791287.

Ausubel, F.M., R. Brent, R.E. Kingston, D.D. Moore, J.G. Seidman, J.A. Smith, and K. Struhl. 1989. Current Protocols in Molecular Biology. Greene/Wiley, New York.

Berben, G., J. Dumont, V. Gilliquet, P.-A. Bolle, and F. Hilger. 1991. The YDp plasmids: A uniform set of vectors bearing versatile gene disruption cassettes for Saccharomyces cerevisiae. Yeast 7: 475-477.

Boeke, J.D., F. LaCroute, and G.R. Fink. 1984. A positive selection for mutants lacking orotidine- 5 '-phosphate decarboxylase activity in yeast: 5-fluoro-orotic acid resistance. Mol. Gen. Genet. 197: 345-346.

Boeke, J.D., J. Trueheart, G. Natsoulis, and G.R. Fink. 1987. 5 -Fluoroorotic acid as a selective agent in yeast molecular genetics. Methods Enzymol. 154: 164-175.

Borst, P. 1991. Molecular genetics of antigenic variation. Im munol. Today 12: A29-33.

Braunstein, M., A.B. Rose, S.G. Holmes, C.D. Allis, and J.R. Broach. 1993. Transcriptional silencing in yeast is associated with reduced nucleosome acetylation. Genes \& Dev. 7: 592604.

Brown, D.D. 1984. The role of stable complexes that repress and activate eukaryotic genes. Cell 37: 359-365.

Choder, M. 1991. A general topoisomerase I-dependent transcriptional repression in the stationary phase of yeast. Genes \& Dev. 5: 2315-2326.

Cross, G.A. 1990. Cellular and genetic aspects of antigenic variation in trypanosomes. Annu. Rev. Immunol. 8: 83-110.

Durrin, L.K., R.K. Mann, P.S. Kayne, and M. Grunstein. 1991. Yeast histone $\mathrm{H} 4 \mathrm{~N}$-terminal sequence is required for promoter activation in vivo. Cell 65: 1023-1031.

Eissenberg, J.C. 1989. Position effect variegation in Drosophila: Towards a genetics of chromatin assembly. Bioessays 11: 14-17.

Felsenfeld, G. 1992. Chromatin as an essential part of the tran scriptional mechanism. Nature 355: 219-224.

Fleig, U.N., R.D. Pridmore, and P. Philippsen. 1986. Construction of LYS2 cartridges for use in genetic manipulations of Saccharomyces cerevisiae. Gene 46: 237-245.

Gottschling, D.E. 1992. Telomere-proximal DNA in Saccharomyces cerevisiae is refractory to methyltransferase activity in vivo. Proc. Natl. Acad. Sci. 89: 4062-4065.

Gottschling, D.E., O.M. Aparicio, B.L. Billington, and V.A. Za- kian. 1990. Position effect at $S$. cerevisiae telomeres: Reversible repression of Pol II transcription. Cell 63: 751-762.

Guacci, V., E. Hogan, and D. Koshland. 1994. Chromosome condensation and sister chromatid pairing in budding yeast. $J$. Cell Biol. (in press).

Hartwell, L.H. 1976. Sequential function of gene products relative to DNA synthesis in the yeast cell cycle. J. Mol. Biol. 104: 803-817.

Henikoff, S. 1990. Position-effect variegation after 60 years. Trends Genet. 6: 422-426.

Henikoff, S. and M.K. Eghtedarzadeh. 1987. Conserved arrangement of nested genes at the Drosophila Gart locus. Genetics 117: 711-725.

Innis, M.A., D.H. Gelfand, J.J. Sninsky, and T.J. White, ed. 1990. PCR Protocols: A guide to methods and applications Academic Press, Inc., San Diego, CA.

Ito, H., Y. Jukuda, K. Murata, and A. Kimura. 1983. Transformation of intact yeast cells treated with alkali cations. $J$. Bacteriol. 153: 163-168.

Jacobs, C.W., A.E. Adams, P.J. Szaniszlo, and J.R. Pringle. 1988. Function of microtubules in the Saccharomyces cerevisiae cell cycle. J. Cell Biol. 107: 1409-1426.

Johnson, L.M., P.S. Kayne, E.S. Kahn, and M. Grunstein. 1990. Genetic evidence for an interaction between SIR3 and histone $\mathrm{H} 4$ in the repression of silent mating loci in Saccharomyces cerevisiae. Proc. Natl. Acad. Sci. 87: 6286-6290.

Johnston, M. 1987. A model fungal gene regulatory mechanism: the GAL genes of Saccharomyces cerevisiae. Microbiol. Rev. 51: 458-476.

Johnston, M. and R.W. Davis. 1984. Sequences that regulate the divergent GAL1-GAL10 promoter in Saccharomyces cerevisiae. Mol. Cell. Biol. 4: 1440-1448.

Johnston, M. and J. Dover. 1988. Mutational analysis of the GAL4-encoded transcriptional activator protein of Saccharomyces cerevisiae. Genetics 120: 63-74.

Kyrion, G., K. Liu, C. Liu, and A.J. Lustig. 1993. RAP1 and telomere structure regulate telomere position effects in Saccharomyces cerevisiae. Genes \& Dev. 7: 1146-1159.

Lacroute, F. 1968. Regulation of pyrimidine biosynthesis in Saccharomyces cerevisiae. J. Bacteriol. 95: 824-832.

Laurenson, P. and J. Rine. 1992. Silencers, silencing, and heritable transcriptional states. Microbiol. Rev. 56: 543-560.

Lilielund, P., R. Losson, B. Kammerer, and F. Lacroute. 1984. Yeast regulatory gene PPR1. II. Chromosomal localization, meiotic map, suppressibility, dominance/recessivity and dosage effect. . I. Mol. Biol. 180: 251-265.

Lima-de-Faria, A. 1983. Processes of directing expression, mutation and rearrangements. In Molecular evolution and organization of the chromosome pp. 507-604. Elsevier Science Publishers, Amsterdam.

Losson, R. and F. Lacroute. 1981. Cloning of a eukaryotic regulatory gene. Mol. Gen. Genet. 184: 394-399.

- 1983. Plasmids carrying the yeast OMP decarboxylase structural and regulatory genes: Transcription regulation in a foreign environment. Cell 32: 371-377.

Losson, R., R.P. Fuchs, and F. Lacroute. 1985. Yeast promoters URA1 and URA3. Examples of positive control. J. Mol. Biol. 185: 65-81.

McCarroll, R.M. and W.L. Fangman. 1988. Time of replication of yeast centromeres and telomeres. Cell 54: 505-513.

Miller, A.M. and K.A. Nasmyth. 1984. Role of DNA replication in the repression of silent mating type loci in yeast. Nature 312: 247-251.

Nasmyth, K., A. Seddon, and G. Ammerer. 1987. Cell cycle regulation of SWI5 is required for mother-cell-specific HO transcription in yeast. Cell 49: 549-558. 
Palladino, F., T. Laroche, E. Gilson, A. Axelrod, L. Pillus, and S.M. Gasser. 1993. SIR3 and SIR4 proteins are required for the positioning and integrity of yeast telomeres. Cell 75: 543-555.

Pillus, L. and F. Solomon. 1986. Components of microtubular structures in Saccharomyces cerevisiae. Proc. Natl. Acad. Sci. 83: 2468-2472.

Piñon, R. 1978. Folded chromosomes in non-cycling yeast cells. Evidence for a characteristic G0 form. Chromosoma 67: 263-274.

Pringle, J.P. and L.H. Hartwell. 1981. The Saccharomyces cerevisiae cell cycle. In The molecular biology of the yeast Saccharomyces (ed. J.D. Strathern, E.W. Jones, and J.R. Broach), pp. 97-142. Cold Spring Harbor Laboratory, Cold Spring Harbor, New York.

Renauld, H., O.M. Aparicio, P.D. Zierath, B.L. Billington, S.K. Chhablani, and D.E. Gottschling. 1993. Silent domains are assembled continuously from the telomere and are defined by promoter distance and strength, and by SIR3 dosage. Genes \& Dev. 7: 1133-1145.

Rose, M. and F. Winston. 1984. Identification of a Ty insertion within the coding sequence of the $S$. cerevisiae URA3 gene. Mol. Gen. Genet. 193: 557-560.

Roy, A. 1992. Nucleotide sequence of the URAl gene of Saccharomyces cerevisiae. Gene 118: 149-150.

Roy, A., F. Exinger, and R. Losson. 1990. cis- and trans- acting regulatory elements of the yeast URA3 promoter. Mol. Cell. Biol. 10: $5257-5270$.

Runge, K.W. and V.A. Zakian. 1989. Introduction of extra telomeric DNA sequences into Saccharomyces cerevisiae results in telomere elongation. Mol. Cell. Biol. 9: 1488-1497.

Sambrook, J., E.F. Fritsch, and T. Maniatis. 1989. Molecular cloning: A laboratory manual. Cold Spring Harbor Laboratory Press, Cold Spring Harbor, New York.

Schmid, A., K.D. Fascher, and W. Horz. 1992. Nucleosome disruption at the yeast PHO5 promoter upon PHO5 induction occurs in the absence of DNA replication. Cell 71: 853-864.

Sikorski, R.S. and J.D. Boeke. 1991. In vitro mutagenesis and plasmid shuffling: From cloned gene to mutant yeast. Methods Enzymol. 194: 306-311.

Sikorski, R.S. and P. Hieter. 1989. A system of shuttle vectors and yeast host strains designed for efficient manipulation of DNA in Saccharomyces cerevisiae. Genetics 122: 19-27.

Slater, M.L. 1973. Effect of reversible inhibition of deoxyribonucleic acid synthesis on the yeast cell cycle. J. Bacteriol. 113: $263-270$.

Spradling, A.C. and G.H. Karpen. 1990. Sixty years of mystery. Genetics 126: 779-784.

Surosky, R.T. and R.E. Esposito. 1992. Early meiotic transcripts are highly unstable in Saccharomyces cerevisiae. Mol. Cell. Biol. 12: 3948-3958.

Verdier, J.M. 1990. Regulatory DNA-binding proteins in yeast: An overview. Yeast 6: 271-297.

Weintraub, H. 1985. Assembly and propagation of repressed and derepressed chromosomal states. Cell 42: 705-711.

Werner-Washburne, M., E. Braun, G.C. Johnston, and R.A. Singer. 1993. Stationary phase in the yeast Saccharomyces cerevisiae. Microbiol. Rev. 57: 383-401.

Wittenberg, C., K. Sugimoto, and S.I. Reed. 1990. GI-specific cyclins of S. cerevisiae: Cell cycle periodicity, regulation by mating pheromone, and association with the p34CDC28 protein kinase. Cell 62: 225-237. 


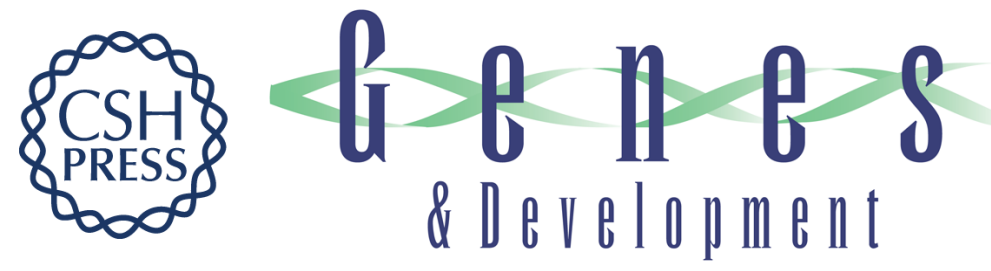

\section{Overcoming telomeric silencing: a trans-activator competes to establish gene expression in a cell cycle-dependent way.}

O M Aparicio and D E Gottschling

Genes Dev. 1994, 8:

Access the most recent version at doi:10.1101/gad.8.10.1133

References This article cites 52 articles, 21 of which can be accessed free at:

http://genesdev.cshlp.org/content/8/10/1133.full.html\#ref-list-1

License

Email Alerting

Service

Receive free email alerts when new articles cite this article - sign up in the box at the top right corner of the article or click here.

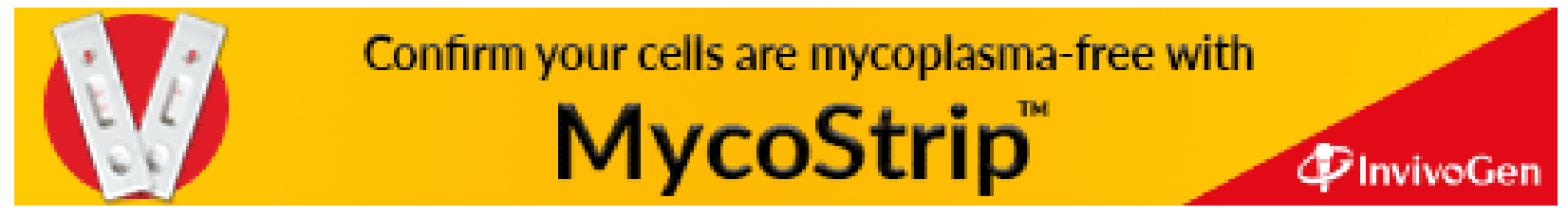

